\title{
Idéhistorisk mastodont i særklasse
}

Espen Schaanning:

Lykkens politikk - Fransk opplysningstid og

synet på menneske og straff bos Helvetius

Akademika forlag, 2013

579 sider, 398 NOK.

For mange er den franske filosof Claude Adrien Helvetius (17151771) nok en af de mindre kendte oplysningstænkere. I sin samtid var han ustandseligt udskældt og ombrust af skandaler, men også læst vidt og bedt. Dette skyldtes særligt hans kontroversielle værk De l'esprit fra 1758, der, som en samtidig teolog erklærede, havde "samlet alle typer gift som finnes spredt i ulike moderne bøker" (s. 296). Udskældt fra alle sider - også af encyklopædisterne og les philosophes - og udelukkelse fra det gode selskab har måske været medvirkende til, at han sidenhen ofte er blevet udeladt af filosofihistorien. Det er sjældent, at Helvetius placeres som omdrejningspunkt og hovedfokus i større idéhistoriske studier af den franske oplysning. Særligt i den skandinaviske forskning bliver han ofte forsømt eller forbigået. Netop dette forsøger den norske professor i idéhistorie ved Universitetet i Oslo Espen Schaanning dog at rode bod på med mastodontværket Lykkens Politikk. Ved at læse den franske oplysning gennem Helvetius sætter Schaanning sig i denne bog for at undersøge, hvordan nye tanker om særligt strafferet udfoldede sig i sammenspil med debatter om bl.a. videnskab, religion og opdragelse.

Bogens 13 kapitler er opdelt i 2 dele. I bogens første del behandler Schaanning tiden op til og omkring Helvetius særligt ud fra centrale problematikker i den franske oplysningstid, såsom videnskab, moral, opdragelse og politisk filosofi. Anden del omhandler Helvetius' egen filosofi med fokus på hans syn på menneske og straf. Her er særligt værket De l'esprit Schaanning sætter i centrum - både $\mathrm{i}$ forhold til dets rent argumentatoriske niveau og dets udgivelses- og receptionshistorie. I bogens afsluttende kapitel 
forsøger Schaanning endvidere at skitsere forskellige transformationer i den norske strafferetstænkning fra Helvetius' tid til i dag. Bogens to dele kan sagtens læses hver for sig som henholdsvis en glimrende introduktion til den franske oplysning samt forskningen tilknyttet denne og et grundigt studie af Helvetius virke og tænkning. Helvetius' syn på menneske og straf var ikke unikke som sådan i den franske oplysningskontekst og pendanter kunne således sagtens findes hos mange andre oplysningsfilosoffer. Det skandaløse bestod snarere i radikalisereingen af disse tanker. Schaannings argument er således heller ikke, at alle disse tanker startede og sluttede med Helvetius, men derimod at det er muligt at anskue Helvetius som et samlingspunkt for og udfoldelse af forskellige tanker $i$ den franske oplysning om straf, samfund og menneske.

Med bogens titel, Lykkens politike, henviser Schaanning til det, han identificerer som et centralt samfundsprojekt i oplysningen, nemlig projektet om at gøre flest mulige mennesker i samfundet lykkelige. I et straffehistorisk perspektiv forudsætter denne lykkens politik dog paradoksalt nok også en smertens politik i form af en såkaldt tilsigtet smerte. Dette forhold bliver netop eksemplificeret i Helvetius' syn på menneske og straf. For Helvetius er mennesket først og fremmest styret af at ville undgå smerte og opnå lykke og nydelse. Det er således vigtigt at lovgiveren både belønner sine borgere for samfundsmæssigt gode og fremmende handlinger og ligeledes straffer dem for samfundsmæssigt dårlige og nedbrydende handlinger. Formålet med straffen er således snarere at disciplinere borgerne end at pine den enkelte. Af netop denne grund skal straffen også tilhøre og udfoldes i det sociale og offentlige rum. Nøglebegrebet i Helvetius' forestilling om menneske og straf er anerkendelse. Dette virker muligvis overraskende, som Schaanning også selv fremhæver: "Lenge før Hegel, lenge for Habermas, lenge før Honneth, pekte Helvetius på anerkjennelsen, interaksjonen mellom borgerne, som det limet som knyttet menneskene sammen" (s. 516). Ifølge Helvetius er anerkendelse den bedste belønning et menneske kan få, mens tabet af anerkendelse omvendt er den værste straf. Det er netop af denne grund Helvetius foreslår offentlig straf, i form af vanære og udstilling, fremfor fængselsstraf som afstraffelsesmetode. Straffen skal således ikke findes i isolation, pisk eller tortur, men i det sociale. 
Der er en klar, tilbagevendende og klassisk idéhistorisk ambition med bogen om at afselvfølgeliggøre vores nutidige opfattelse af strafferet og afstraffelsesformer. I det 18. århundrede var fængsling langt fra en almen afstraffelsesform. Hvad der for de fleste i dag synes at være den mest selvfølgelige form for straf, var i tiden før den franske revolution end ikke indskrevet i de franske love. Heller ikke blandt de berømte, franske oplysningsfilosoffer var fængslet og fængslingen den fortrukne eller foreslåede metode. Efter Reformationen og i løbet af det 17. århundrede var den gamle kristne gengældelseslære langsomt blevet erstattet med mosaisk ret. Frem for øje for øje blev retfærdighed et styrende princip, med kongen som repræsentant fremfor kirken. Først i det 19. århundrede faldt religionen imidlertid helt som grundsten for strafferetten. Denne baseredes herefter på det, man har betegnet som den samfundsmæssige retsfølelse. Den menneskelige retsfølelse blev nu forvaltet af staten ud fra rationelle og fornuftige principper. Overgangen til den moderne strafferet, som vi kender den, opstod først og fremmest i Oplysningstiden. Her forsøgte en række tænkere at gentænkte strafferetten i overensstemmelse med oplysningens nye menneske- og samfundssyn. Én af disse var Helvetius.

Generelt udfylder Schaanning med Lykkens politike en tom plads i forskningen. Særligt set med skandinaviske øjne har der manglet en samlet fremstilling af fransk oplysningsfilosofi og af Helvetius' filosofi og syn på menneske og straf. I denne optik er bogen et særdeles kærkomment bidrag. Bogen tjener på alle måder som en fremragende og grundig indføring i Helvetius som tænker og i forskningen omkring ham. Der er tale om et velskrevet, imponerende og særdeles relevant idéhistorisk værk, der henvender sig til alle med interesse for det 18. århundrede og straffetænkningens idéhistorie. Schaannings fremstilling er både overbevisende og fængende skrevet, og det er i det hele svært at finde noget negativt at udsætte på værket. Alt $i$ alt er der tale om en læseværdig og anbefalelsesværdig bog.

Eva Krause Jorgensen 